\title{
WEED DYNAMICS, YIELD, QUALITY AND ROOT GROWTH OF CAPSICUM UNDER DRIP IRRIGATION AND MULCHING
}

\author{
V. K. Choudhary ${ }^{1}$, M. C. Bhambri and N. Pandey \\ Department of Agronomy, Indira Gandhi Agricultural University, Raipur-492 006, India
}

\begin{abstract}
A field experiment was conducted during 2006-07 and 2007-08 at Precision Farming Development Centre, Horticulture Farm, Indira Gandhi Agricultural University, Raipur, Chhattisgarh, India to evaluate the weed dynamics, yield, quality, organoleptic parameters and root growth of Capsicum as influenced by drip irrigation and mulches. The black polythene mulch being at par with paddy straw mulch gave the least weed population, dry weight and highest weed control efficiency over other mulches. Drip irrigation at 0.6 Epan obtained the least value of weed growth and highest weed control efficiency. Drip irrigation at 1.0 Epan showed highest fruit yield (32.02 $\left.\mathrm{t} \mathrm{ha}^{-1}\right)$, total soluble solid (5.72), ascorbic acid $(120.25 \mathrm{mg}$ $100 \mathrm{~g}^{-1}$ ) and organoleptic parameters but root growth registered maximum in flood irrigation at 1.0 IW/CPE. Black polythene followed by paddy straw mulch showed maximum fruit yield and other parameters. Pungent test scored maximum with flood irrigation at 1.0 IW/CPE and no mulch. Drip irrigation at 1.0 Epan along with black polythene as well as paddy straw mulch restrict weed growth, harvested quality fruit with higher fruit yield of capsicum.
\end{abstract}

Key words: Capsicum, drip irrigation, mulch, quality, root growth, weed dynamics

\section{INTRODUCTION}

Capsicum (Capsicum annum L.) is one of the important commercial crops of India. It is a crop of tropical and sub-tropical regions and requires a warm humid climate. It is rich source of vitamin A and $\mathrm{C}$ with good medicinal properties. Among the spices consumed per head, dry capsicum fruits constitute a major share. Recently, formulated flavour extracts called 'Capsicum oleoresin' has varied uses in processed food and beverage industries (Dhar and Majumdar, 2006). Capsicum being a long duration crop, maintaining soil moisture and weed free status throughout its growth

\footnotetext{
${ }^{1}$ Corresponding author email: ind_vc@rediffmail.com
} 
period is crucial for getting higher yield. Under these circumstances, drip irrigation along with mulching are good approaches for efficient means of applying water and maintaining weed free condition. In drip irrigation, water is applied directly to root zone around the plants through a pipe network with the help of emitters near the plants. Thereby conveyance and distribution losses of water could be minimized substantially. Although drip irrigation requires higher initial installation cost, but due to its major advantages such as high benefit cost ratio, minimum disease and pest incidence and saving energy and labour, compensate its higher initial cost (Choudhary et al., 2006 and Ertek et al., 2007). Mulching conserve soil moisture through less evaporation losses and also improve the soil properties, thereby produce better fruit quality with less weeds, disease and pest etc. (Samedani and Rahimian, 2006). The present study was carried out to study the weed dynamics, root growth and quality, organoleptic parameters and yield of capsicum under drip irrigation and mulches.

\section{MATERIALS AND METHODS}

A field study was conducted at Precision Farming Development Centre, Horticulture Farm, Indira Gandhi Agricultural University, Raipur (India) during 2006-07 and 2007-08. The experimental site receives an average annual rainfall of $1200-1400 \mathrm{~mm}$ and most of which (about 85\%) is concentrated from third week of June to mid September and little during October and February. The soil of the experimental site was silty clay loam, neutral in reaction $(\mathrm{pH} 7.06)$, medium in organic carbon $(0.49 \%)$, low in available nitrogen $\left(236.5 \mathrm{~kg} \mathrm{ha}^{-1}\right)$, medium in available $\mathrm{P}\left(18.8 \mathrm{~kg} \mathrm{ha}^{-1}\right)$, high in available $\mathrm{K}\left(310.5 \mathrm{~kg} \mathrm{ha}^{-1}\right)$ and normal in EC (0.42 $\mathrm{dS} \mathrm{m}^{-1}$ at $25^{\circ} \mathrm{C}$ ). Capsicum (var. Agnirekha) was taken as test crop during study. The experiment was laid out in split plot design with three replications. Four irrigation levels [i.e. $\mathrm{L}_{1}: 1.0$ Epan (pan evaporation) through drip, $\mathrm{L}_{2}: 0.8$ Epan through drip, $\mathrm{L}-$ 3: 0.6 Epan through drip and $\mathrm{L}_{4}: 1.0 \mathrm{IW} / \mathrm{CPE}$ through flood irrigation (FI)] were allotted to main plots and four mulching treatments i.e. $\mathrm{M}_{1}$ : No mulch along with glyphosate@6.0 $\mathrm{ml} \mathrm{l}^{-1}$ with $6001 \mathrm{ha}^{-1}$ of water followed by 2 hand weeding at 26 and 51 DAP, $\mathrm{M}_{2}$ : Black polythene mulch (BPM; $40 \mu$ thickness), $\mathrm{M}_{3}$ : Transparent polythene mulch (TPM; $40 \mu$ thickness), $\mathrm{M}_{4}$ : Paddy straw mulch (PSM; $5 \mathrm{t} \mathrm{ha}^{-1}$ ) were allotted to sub-plots. Seedlings were raised in a nursery and after preparing the main field, 35 days old seedlings were transplanted on $1^{\text {st }}$ October, 2006 and $3^{\text {rd }}$ October, 2007 , respectively with the gross plot area of $4.80 \mathrm{~m} \mathrm{x} 5.40 \mathrm{~m}\left(25.9 \mathrm{~m}^{2}\right)$ and net area of $2.40 \mathrm{~m} \times 4.50 \mathrm{~m}\left(10.8 \mathrm{~m}^{2}\right)$. The capsicum crop was nourished with fertilizer dressing@180 kg N, $120 \mathrm{~kg} \mathrm{P}$ and $120 \mathrm{~kg} \mathrm{~K} \mathrm{ha}^{-1}$. Nitrogen was applied in three split doses i.e. $50 \%$ at basal, $25 \%$ at 30 DAT and rest $25 \%$ at 50 DAT and entire quantity of phosphorus along with potash was applied as basal dose and thoroughly mixed in soil. Spacing $(60 \mathrm{~cm} \times 45 \mathrm{~cm})$ was maintained as per recommendation. All other cultural practices were done as per standard recommendation for capsicum. Drip laterals were placed on $8^{\text {th }}$ DAP (days after planting) and started imposing the allotted treatments from 10 DAP. Mulches were placed on the planted bed carefully 12 DAP 
as per the quantity given in treatments. Glyphosate @ $6.0 \mathrm{ml} \mathrm{l}^{-1}$ was sprayed 26 DAP for both the years by using flat nozzle with the help of using card board above nozzle to protect the drift hazards. The total water used ranges from 334.6 to $531.8 \mathrm{~mm}$ during 2006-07 and 311.1 to $510.2 \mathrm{~mm}$ during 2007-08. Cost of mulch was Rs 65 $\mathrm{kg}^{-1}$ (1USD equivalent to $45 \mathrm{Rs}$ ) and Rs 400/ha/irrigation charge for water. Flood irrigation required 15 irrigations throughout the crop period. There were six picking of capsicum fruits which started from $20^{\text {th }}$ and $22^{\text {nd }}$ January during 2007 and 2008 respectively and final harvests were done on $11^{\text {th }}$ and $12^{\text {th }}$ March during 2007 and 2008 respectively.

Weed parameters (weed density, weed dry weight, weed control efficiency and weed index) were recorded during critical competition period (25, 50 and 75 DAP), fruit yield was recorded as per picking and cumulative has been used for drawing final yield. Quality parameters like total soluble solids (TSS), ascorbic acid and capsicin were measured. Besides, root growth parameters (i.e. maximum root length, root numbers, root volume, root dry weight, root density and root fractions) and organoleptic parameters (i.e. appearance, colour, shining, juiciness and pungency) were measured. Statistical analysis was carried out using standard agricultural statistical package (AGRES).

\section{RESULTS AND DISCUSSION}

\section{Weed dynamics}

Among the dominant weed species observed in experimental field, Cyperus rotundus was the only sedge, Echinochloa colona, Cynodon dactylon and Brachiaria ramose were major grasses and Parthenium hysterophorus, Physalis minima, Melilotus alba, Chenopodium album, Convolvulus arvensis were the major broad leaves weeds.

\section{Weed density and weed dry weight}

Weed density and weed dry weight were minimum with drip irrigation at 0.6 Epan followed by drip irrigation at 0.8 Epan at different days after planting. However, flood irrigation at $1.0 \mathrm{IW} / \mathrm{CPE}$ registered maximum value of weed density and weed dry weight (Table 1). These might be due to the restricted wetting area near the plant parts in drip irrigated plants. The density and dry weights were more because flood irrigation induces the weed seeds to germinate and emerge quickly. Among the mulches, black polythene mulch recorded the minimum weed density and weed dry weight throughout the crop growth period. However, the maximum weed density and weed dry biomass throughout the crop growth period were observed with no mulch. It was also noticed that transparent polythene mulch induces Echinochloa colona and Cynodon dactylon grasses to emerge quickly over others. It might be due to the fact that the grasses are having the higher photosynthetic efficiency and can absorb even long wave radiation which was emitted from the soil. Most of the inferior quality of radiations was filtered by transparent polythene and only good 
quality radiation was transmitted through the polythene (Orzolek, 1995). But sedges and broadleaves were more with no mulch having profuse canopy coverage and high competing ability. The growth of weeds was less in paddy straw mulch followed by black polythene mulch. Weeds emerged only near the plants where holes were made on black polythene mulch, whereas in paddy straw mulch weeds emerged in the area where solar radiation was penetrated. It might be due to the unavailability of solar radiation which restricts the weed seeds to germinate and emerge as black polythene mulch completely restricts the penetration of light to soil, whereas paddy straw mulch allows restricted penetration of solar radiation by zigzag motion.

\section{Weed control efficiency}

Drip irrigation at 0.6 Epan obtained $51.2 \%$ weed control efficiency (WCE) followed by 0.8 and 1.0 Epan (45.3 and $38.1 \%$ respectively); whereas, the lowest WCE was recorded with flood irrigation at $1.0 \mathrm{IW} / \mathrm{CPE}$ (Table 1). Flood irrigation induces the weed seeds of seed bank to germinate and provide congenial condition for further growth from entire area. Drip irrigation generally suppress the weed seeds to germinate; whereas, wet region favours the weeds growth. Among the different mulches, black polythene mulch had maximum WCE (72.9\%) followed by paddy straw mulch (32.9\%). Maximum weeds were found in no mulch followed by transparent polythene mulch. Lesser weed germination and infestation by restricting the penetration of solar radiation under black polythene mulch resulted in higher weed control efficiency. Transparent polythene mulch induced the germination of grasses therefore WCE was comparatively lower (Patel et al., 2009).

\section{Weed Index}

The weed index was maximum in flood irrigation at 1.0 IW/CPE (36.0) followed by drip irrigation at 0.6 Epan (20.2). The maximum weed index (27.8) was recorded from no mulch followed by transparent polythene mulch and paddy straw mulch (20.7 and 5.9 respectively).

\section{Fruit yields}

Drip irrigation at 1.0 Epan recorded the highest capsicum yield $\left(32.02 \mathrm{t} \mathrm{ha}^{-1}\right)$ which was statistically at par with drip irrigation at 0.8 Epan $\left(29.90 \mathrm{t} \mathrm{ha}^{-1}\right)$. However, flood irrigation at $1.0 \mathrm{IW} / \mathrm{CPE}$ had the lowest yield $\left(20.52 \mathrm{t} \mathrm{ha}^{-1}\right)$. Black polythene mulch recorded maximum yield $\left(31.24 \mathrm{t} \mathrm{ha}^{-1}\right)$ followed by paddy straw mulch $(29.40$ $\left.\mathrm{t} \mathrm{ha}^{-1}\right)$. Lowest yield was obtained from no mulch followed by transparent polythene mulch (22.56 and $24.77 \mathrm{t} \mathrm{ha}^{-1}$ respectively).

Drip irrigation at 1.0 and 0.8 Epan supplied water drop by drop with slow flow rate which restricted the water losses and allowed the plants to absorb available soil moisture from the root zone and thereby increased the productivity of capsicum. Flood irrigation at 1.0 IW/CPE had reduced the capsicum yield by 56.12, 45.73 and $24.52 \%$ compared to drip irrigation at 1.0, 0.8 and 0.6 Epan respectively (Table 2). Under flood irrigation at $1.0 \mathrm{IW} / \mathrm{CPE}$ most of the applied water was lost through 
evaporation and leaching due to fast rate of application. This also favoured to grow more weeds and competed with the capsicum crop for nutrient and moisture, which directly reduced the capsicum yield. Capsicum yield showed inverse linear relationship with weed dry weight $\left(\mathrm{R}^{2}=0.60\right)$. Similarly, Choudhary et al., (2006) also reported that under flood irrigation, the crop experienced excess moisture (water stagnation) conditions in the beginning, which enhanced the leaching of available nutrients. The crop was under favourable condition only for a short span of time and due to high evaporation rate from soil surface most of the water was lost and at the end of the irrigation cycle, availability of moisture became insufficient, which created water stress.

Placement of black polythene mulch registered $6.25,26.12$ and $28.48 \%$ higher yield of capsicum, than paddy straw mulch, transparent polythene mulch and no mulch, respectively. Vos and Sumarni (1997) also reported that crop under black polythene mulch and paddy straw mulch had higher chlorophyll content which enhances the carbon dioxide and other gasses exchange and ultimately leads to higher photosynthesis and transpiration. Therefore, dry matter accumulation and partitioning was better at different plant parts and enhanced crop growth parameters and capsicum yield than other mulches.

\section{Quality parameters}

Flood irrigation of capsicum at $1.0 \mathrm{IW} / \mathrm{CPE}$ recorded maximum total soluble solids $(5.72 \%)$ followed by drip irrigation at 0.6 Epan $(5.39 \%)$. Capsicin showed highest values in drip irrigation at 1.0 Epan $(0.40 \%)$. However, TSS and capsicin values were lower with drip irrigation at 1.0 Epan (4.16 and $0.26 \%$ respectively) followed by drip at 0.8 Epan (Table 2). In contrary, ascorbic acid content was higher with drip irrigation at 1.0 Epan $\left(121.27 \mathrm{mg}_{100 \mathrm{~g}^{-1}}\right)$ followed by drip irrigation at 0.8

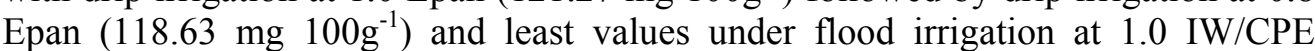
followed by drip at 0.6 Epan. Black polythene mulch (4.50 and $0.29 \%$ respectively) and paddy straw mulch (4.60 and $0.30 \%$ respectively) had lower TSS and capsicin. Maximum TSS and capsicin were measured with no mulch followed by transparent polythene mulch. In contrary ascorbic acid was maximum with black polythene mulch $\left(119.92 \mathrm{mg} 100 \mathrm{~g}^{-1}\right)$ followed by paddy straw mulch and least with no mulch

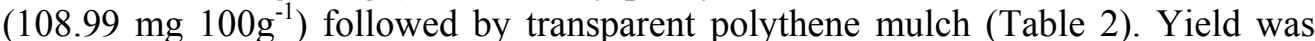
inversely linearly related with TSS and capsicin $\left(\mathrm{R}^{2}=0.93\right)$, whereas, positive linear relationship $\left(\mathrm{R}^{2}=0.98\right)$ was observed with ascorbic acid content (Figure. $\left.2 \mathrm{a}, \mathrm{b}, \mathrm{c}\right)$.

Higher TSS and capsicin with flood irrigation at 1.0 IW/CPE and no mulch is due to high accumulation of soluble solids which helps plant not to loose water from their fruits to sustain against stresses. The increased amount of capsicin content of fruit could be attributed to the increased cell metabolism, enzymatic activity and mineral composition (Dhar and Majumdar, 2006). In black polythene mulch and drip irrigation at higher levels, the availability of water and nutrients were better. Similarly, with paddy straw mulch the activity of microbes might have increased with 
decomposition of it, which in turn increases inavailability of nutrients. Higher microbial activity leads to secretion and formation of organic acid which was directly up taken by plants and this leads to higher ascorbic acid (Mahendaren and Bandara, 2000).

\section{Root growth}

Flood irrigation at 1.0 IW/CPE showed maximum root length, root number, root volume and root dry weight at 120 DAP $\left(30.89 \mathrm{~cm}, 29.41,26.69 \mathrm{~cm}^{3}\right.$ and 11.62 $\mathrm{g}$ respectively) followed by drip irrigation at 0.6 Epan $\left(29.25 \mathrm{~cm}, 26.16,24.28 \mathrm{~cm}^{3}\right.$ and $10.26 \mathrm{~g}$ respectively). Whereas, low value of all root growth parameters were recorded in drip irrigation at 1.0 Epan followed by 0.8 Epan (Table 3) which might be due to low availability of water with flood irrigation at $1.0 \mathrm{IW} / \mathrm{CPE}$. Crop plants suffered from adverse condition during first 1-3 days of irrigation cycle due to suffocation and stress at the end of irrigation cycle. The unavailability of water helps the plant roots to grow still deeper thereby most of the photosynthates were translocated towards the roots and these were further utilized for growth and development. It was also noticed that with flood irrigation at $1.0 \mathrm{IW} / \mathrm{CPE}$, roots were more fibrous and branched. When photosynthates were translocated towards roots and again partitioned according to need of the plants. Most of the photosynthates were translocated and burned to produce fibrous roots and rest was used for normal growth and development (Sahu, 2003 and Choudhary, 2005-06). No mulch recorded maximum root length, root number, root volume and root dry weight $30.74 \mathrm{~cm}$, $28.01,25.99 \mathrm{~cm}^{3}$ and $11.06 \mathrm{~g}$ respectively) followed by transparent polythene mulch. Poor root growth parameters were observed with black polythene mulch followed by paddy straw mulch (Table 3 ). This was mainly due to low availability of water for crop plants in above cited two treatments. There was more competition for water among crop plants and weeds and rate of evaporation was also higher in no mulch because of completely exposed area. However, with black polythene mulch and paddy straw mulch the loss of water was very meager due to less exposed area and low weed density. These led to uptake water by plant for longer time with sufficient quantity therefore the development of root was near the surface of ground. Yield was inversely linearly related with root dry weight $\left(\mathrm{R}^{2}=0.98\right)$ (Figure. $2 \mathrm{~d}$ ).

Root density was not consistent with irrigation levels and mulches. Maximum root fraction was observed on top soil with drip irrigation at 1.0 Epan $(47.0 \%)$ followed by drip irrigation at 0.8 and 0.6 Epan (Figure. 3). But comparatively higher root fraction was recorded with drip irrigation at 0.6 Epan on deeper soil over upper soil $(11.8 \%)$ and vice versa on higher level of drip irrigation $(2.0 \%)$. However, flood irrigation at $1.0 \mathrm{IW} / \mathrm{CPE}$ had more root fraction at lower layer than upper layer which was contrary to drip irrigation levels. Comparatively higher root fraction was also noticed at more distances from plant, than near the plant with flood irrigation at 1.0 IW/CPE. Maximum root canopy was noticed with flood irrigation at $1.0 \mathrm{IW} / \mathrm{CPE}$ over other drip irrigation levels. Black polythene mulch and paddy straw mulch had 
shallow root depth near the plant (Figure 1). This was mainly due to availability of enough moisture on surface soil which restricts the excessive growth of roots. However, no mulch and transparent polythene mulch showed different root behavior.

\section{Organoleptic parameters}

Drip irrigation at 1.0 Epan secured maximum score with respect to appearance, colour, shining and juiciness of green capsicum over other drip irrigation levels at 0.8 and 0.6 Epan. However, the least score was recorded with flood irrigation at 1.0 IW/CPE. But, shining score was least with drip irrigation at 0.6 Epan. On the other hand, flood irrigation at 1.0 IW/CPE secured the higher score for pungency over others. Similar finding was also reported by Choudhary et al., (2006). Black polythene mulch secured the highest score of appearance, colour and juiciness over others. However, the least score was secured by crop with no mulch. Whereas, shining score was high with transparent polythene mulch and least with paddy straw mulch. On contrary, juiciness was least scored with transparent polythene mulch. Pungency scored high with no mulch and least with black polythene mulch (Table 4).

However, the interaction between drip irrigation levels and mulches were not statistically significant.

\section{CONCLUSION}

Use of drip irrigation at 1.0 Epan registered the higher fruit yield of capsicum along with better quality. But drip irrigation at 0.8 Epan had equally good to drip irrigation at 1.0 Epan. During the study capsicum used the total water from 311.1 to $531.8 \mathrm{~mm}$. However, among the mulches black polythene as well as paddy straw mulch restricts the weed growth and harvested quality capsicum with higher fruit yield. Therefore, as per availability of irrigation water and mulches could be used to harvest better quality capsicum with higher fruit yield.

\section{REFERENCES}

Choudhary, V. K., Ramachandrappa, B. K. and Nanjappa, H. V.2006. Influence of planting methods and drip irrigation levels on total water requirement, yield, water use efficiency and root characters in Baby corn (Zea mays L.). Mysore J. Agric. Sci., 40(2): 189-193.

Choudhary, V. K., Ramachandrappa, B. K., Nanjappa, H. V. and Bachkaiya, Choudhary, V. K., Ramachandrappa, B. K. and Nanjappa, H. V. 2005-06. Yield, economics, quality, sensory evaluation and solar radiation interception as influenced by planting methods and drip irrigation levels in Baby corn (Zea mays L.) vegetable. J. Asian Hort., 2(1): 45-48.

Dhar, S. and Majumdar, T. K. 2006. Changes in different metabolites in developing chilli fruit. Indian J. Hort., 63(1): 24-26.

Ertek, A., Sensoy, S., Gedik, I. and Kucukyumuk, C. 2007. Irrigation scheduling for green pepper (Capsicum annum L.) grown in field condition by using class-A pan evaporation values. American- Eurasian J. Aric. \& Environ. Sci.,. 2(4): 349-358. 
Mahendran, S. and Bandara, D. C. 2000. Effects of soil moisture stress at different growth stages on vitamin $\mathrm{C}$, capsicin and $\beta$ - carotene contents of chilli (Capsicum annum L.) fruits and their impact on yield. Trop. Agric. Res., 12: 95-106.

Orzolek, M. D. 1995. Over love-hate affair with plastics. Growing for market, 3:15-18.

Patel, D. B., Patel, R. H. and Patel, R. B. 2009. Effect of drip irrigation, mulches and nitrogen fertigation on yield and yield attributes of okra (Abelmoschus esculentus). Indian J. Agric. Sci. 79(1): 12-15.

Sahu, P. 2003. Effect of number of plants per hill and irrigation methods and scheduling on growth, yield and quality of baby corn. M. Sc. Thesis submitted to UAS, Bangalore.

Samedani, B. and Rahimian, H. 2006. Effect of cover crops mulch on weed control in orchards. Pakistan J. Weed Sci. Res., 12(4): 347-352.

Vos, J. G. M. and Sumarni, N. 1997. Integrated crop management of hot pepper (Capsicum spp.) under tropical low land conditions. J. Hort. Sci., 72: 415-424. 
Table 1. Weed density, weed dry weight, weed control efficiency and weed index as influenced by drip irrigation and mulches in capsicum (pooled data of 2 years)

\begin{tabular}{|c|c|c|c|c|c|c|c|c|}
\hline \multirow{2}{*}{ Treatment } & \multicolumn{3}{|c|}{ Weed density $\left(\right.$ no. $\left.\mathrm{m}^{-2}\right)$} & \multicolumn{3}{|c|}{ Weed dry weight $\left(\mathrm{g} \mathrm{m}^{-2}\right)$} & \multirow{2}{*}{$\begin{array}{l}\text { Weed control } \\
\text { efficiency (\%) }\end{array}$} & \multirow{2}{*}{$\begin{array}{l}\text { Weed } \\
\text { index }\end{array}$} \\
\hline & 25 DAP & 50 DAP & 75 DAP & 25 DAP & 50 DAP & 75 DAP & & \\
\hline \multicolumn{9}{|c|}{ Drip irrigation level } \\
\hline 0.8 Epan & $31.6(5.66)$ & $22.7(4.81)$ & $41.1(6.45)$ & $10.42(3.30)$ & $7.74(2.87)$ & $13.90(3.79)$ & 45.3 & 6.7 \\
\hline 0.6 Epan & $28.3(5.37)$ & $19.6(4.48)$ & $37.9(6.19)$ & $9.31(3.13)$ & $6.79(2.70)$ & $12.41(3.59)$ & 51.2 & 20.2 \\
\hline $\mathrm{CD} \mathrm{P}=0.05)$ & 3.0 & 2.1 & 2.9 & 1.36 & 1.33 & 2.66 & & \\
\hline \multicolumn{9}{|l|}{ Mulching } \\
\hline $\mathrm{NM}$ & $44.8(6.73)$ & $34.6(5.93)$ & $54.8(7.44)$ & $19.12(4.43)$ & $13.85(3.79)$ & $23.83(4.93)$ & - & 27.8 \\
\hline $\mathrm{CD}(\mathrm{P}=0.05)$ & 3.1 & 2.8 & 3.60 & 1.54 & 1.78 & 2.87 & & \\
\hline
\end{tabular}

FI: Flood irrigation; BPM: Black polythene mulch; TPM: Transparent polythene mulch; PSM: Paddy straw mulch; DAP: days after planting; Figures in parenthesis are square root transformed values $\sqrt{x}+0.5$ 
Table 2. Fruit yield, total soluble solid, ascorbic acid and capsicin as influenced by drip irrigation and mulches in capsicum (pooled data of 2 years)

\begin{tabular}{|c|c|c|c|c|}
\hline Treatment & $\begin{array}{c}\text { Fruit yield } \\
\quad\left(\mathrm{tha}^{-1}\right)\end{array}$ & TSS (\%) & $\begin{array}{c}\text { Ascorbic acid } \\
\left(\mathrm{mg} \mathrm{100g}^{-1}\right)\end{array}$ & $\begin{array}{c}\text { Capsicin } \\
(\%)\end{array}$ \\
\hline \multicolumn{5}{|c|}{ Drip irrigation level } \\
\hline 1.0 Epan & 32.02 & 4.16 & 121.27 & 0.26 \\
\hline 0.8 Epan & 29.90 & 4.61 & 118.63 & 0.30 \\
\hline 0.6 Epan & 25.54 & 5.39 & 113.00 & 0.33 \\
\hline FI (1.0 IW/CPE) & 20.52 & 5.72 & 104.62 & 0.40 \\
\hline $\mathrm{CD}(\mathrm{P}=0.05)$ & 2.66 & 0.38 & 9.79 & 0.05 \\
\hline \multicolumn{5}{|l|}{ Mulching } \\
\hline No Mulch & 22.56 & 5.45 & 108.99 & 0.36 \\
\hline BPM & 31.24 & 4.50 & 119.92 & 0.29 \\
\hline TPM & 24.77 & 5.33 & 111.52 & 0.34 \\
\hline PSM & 29.40 & 4.60 & 117.09 & 0.30 \\
\hline $\mathrm{CD}(\mathrm{P}=0.05)$ & 2.03 & 0.56 & 7.90 & 0.04 \\
\hline
\end{tabular}

FI: Flood irrigation; BPM: Black polythene mulch; TPM: Transparent polythene mulch; PSM: Paddy straw mulch

Table 3. Root growth parameters at 120 DAP as influenced by drip irrigation and mulches in capsicum (pooled data of 2 years)

\begin{tabular}{|c|c|c|c|c|c|}
\hline Treatment & $\begin{array}{c}\text { Root number } \\
\text { plant }^{-1}\end{array}$ & $\begin{array}{l}\text { Root length } \\
\text { (cm) }\end{array}$ & $\begin{array}{l}\text { Root dry weight } \\
\quad\left(\text { g plant }^{-1}\right)\end{array}$ & $\begin{array}{l}\text { Root volume } \\
\left(\mathrm{cm}^{3}\right)\end{array}$ & $\begin{array}{l}\text { Root density } \\
\qquad\left(\mathrm{g} \mathrm{cm}^{-3}\right)\end{array}$ \\
\hline \multicolumn{6}{|c|}{ Drip irrigation level } \\
\hline 1.0 Epan & 23.01 & 27.46 & 8.80 & 22.07 & 0.41 \\
\hline 0.8 Epan & 23.71 & 27.94 & 9.54 & 23.38 & 0.42 \\
\hline 0.6 Epan & 26.16 & 29.25 & 10.26 & 24.28 & 0.43 \\
\hline FI (1.0 IW/CPE) & 29.41 & 30.89 & 11.62 & 26.69 & 0.44 \\
\hline $\mathrm{CD}(\mathrm{P}=0.05)$ & 1.65 & 2.12 & 0.74 & 2.05 & NS \\
\hline \multicolumn{6}{|l|}{ Mulching } \\
\hline $\mathrm{NM}$ & 28.01 & 30.74 & 11.06 & 0.51 & 0.43 \\
\hline BPM & 23.18 & 27.17 & 9.06 & 0.49 & 0.41 \\
\hline TPM & 26.98 & 29.71 & 10.50 & 0.53 & 0.43 \\
\hline PSM & 24.11 & 27.93 & 9.60 & 0.50 & 0.42 \\
\hline $\mathrm{CD}(\mathrm{P}=0.05)$ & 2.82 & 2.61 & 1.08 & NS & NS \\
\hline
\end{tabular}

FI: Flood irrigation; BPM: Black polythene mulch; TPM: Transparent polythene mulch; PSM: Paddy straw mulch; DAP: days after planting 
Table 4. Scores of organoleptic parameters as influenced by drip irrigation and mulches in capsicum (pooled data of 2 years)

\begin{tabular}{|c|c|c|c|c|c|}
\hline Treatment & Appearance & Colour & Shining & Juiciness & Pungency \\
\hline \multicolumn{6}{|c|}{ Drip irrigation level } \\
\hline 1.0 Epan & 3.92 & 4.36 & 3.49 & 4.36 & 2.04 \\
\hline 0.8 Epan & 3.67 & 4.04 & 3.15 & 4.03 & 2.26 \\
\hline 0.6 Epan & 3.3 & 3.31 & 2.64 & 3.28 & 2.87 \\
\hline $\begin{array}{l}\text { FI }(1.0 \\
\text { IW/CPE) }\end{array}$ & 2.83 & 2.98 & 2.68 & 2.95 & 3.28 \\
\hline $\mathrm{CD}(\mathrm{P}=0.05)$ & 0.32 & 0.2 & 0.38 & 0.18 & 0.48 \\
\hline \multicolumn{6}{|l|}{ Mulching } \\
\hline NM & 2.96 & 3.39 & 3.2 & 3.37 & 3.04 \\
\hline BPM & 3.91 & 4.04 & 2.66 & 4.02 & 2.19 \\
\hline TPM & 3.04 & 3.31 & 3.54 & 3.29 & 2.95 \\
\hline PSM & 3.8 & 3.95 & 2.56 & 3.94 & 2.29 \\
\hline $\mathrm{CD}(\mathrm{P}=0.05)$ & 0.38 & 0.4 & 0.37 & 0.41 & 0.53 \\
\hline
\end{tabular}

FI: Flood irrigation; BPM: Black polythene mulch; TPM: Transparent polythene mulch; PSM: Paddy straw mulch; Score: 1: poor; 2: fair; 3: good; 4: very good; 5: excellent

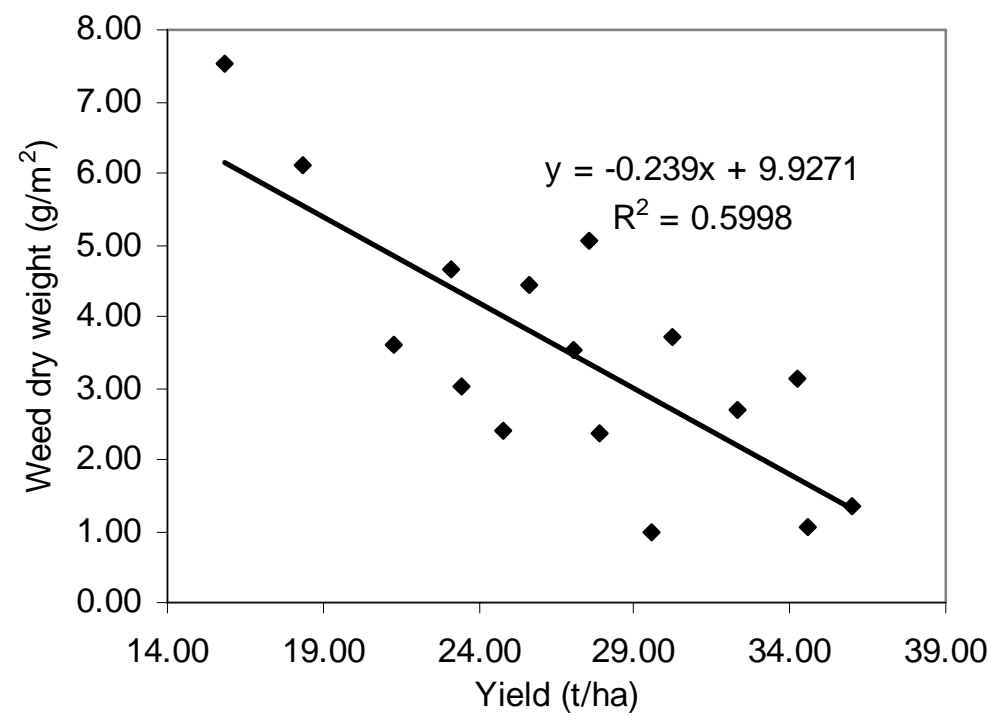

Figure 1. Relationship between yield and weed dry weight as influenced by drip irrigation and mulches in capsicum 
a)

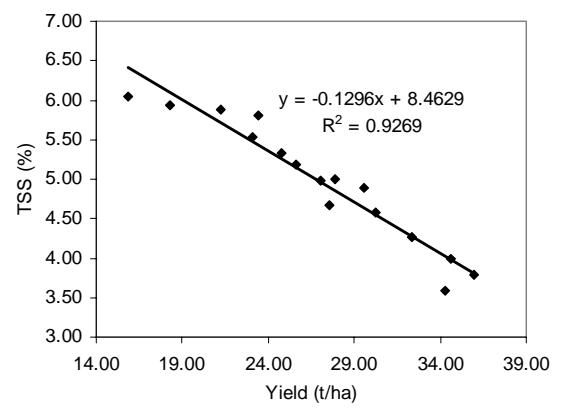

c)

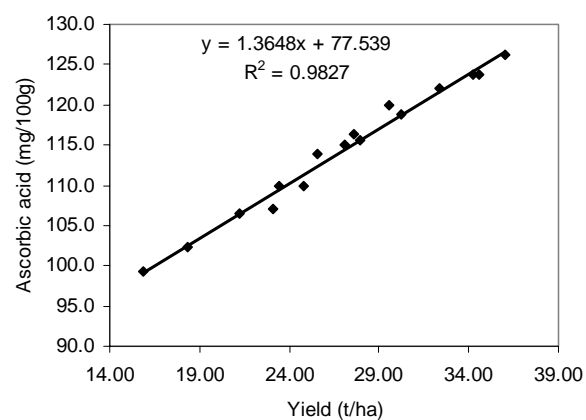

b)

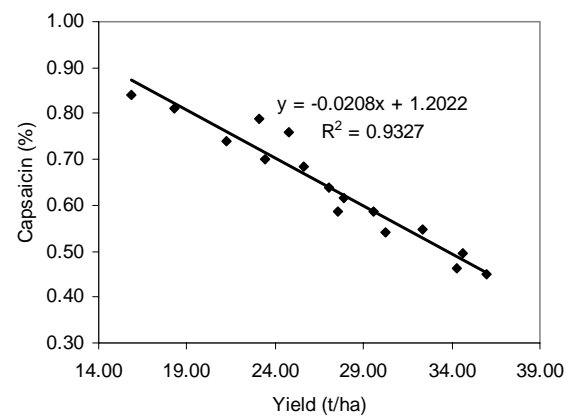

d)

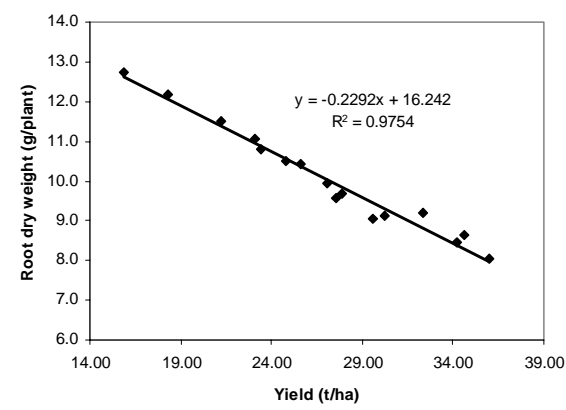

Figure 2. Relationship of yield with a) TSS, b) capsicin, c) ascorbic acid and d) root dry weight as influenced by drip irrigation and mulches in capsicum

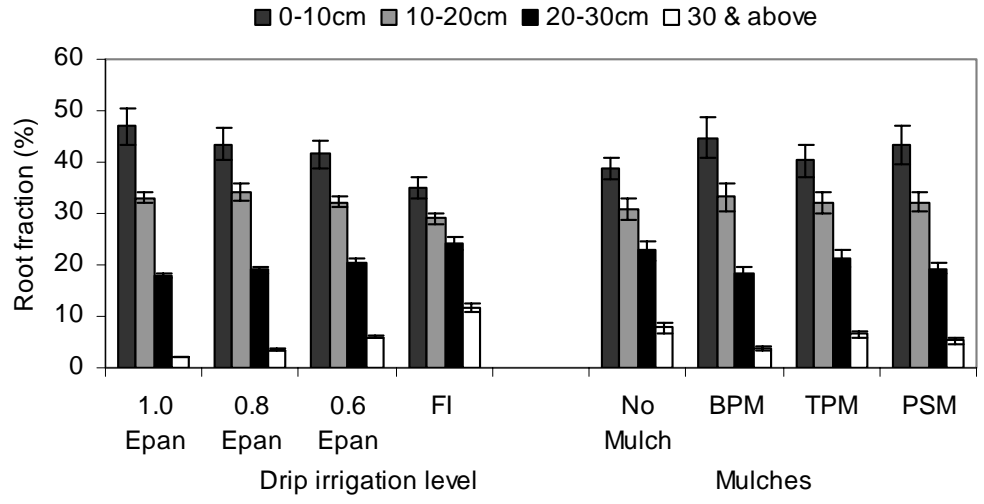

FI: Flood irrigation at 1.0 IW/CPE; BPM: Black polythene mulch; TPM: Transparent polythene mulch; PSM: Paddy straw mulch

Figure 3. Root fractions as influenced by drip irrigation and mulches in capsicum (error bars shows the mean \pm standard deviation) 